\title{
Comparative effects of processing methods on the feeding value of maize in feedlot cattle
}

\author{
R. A. Zinn ${ }^{1 *}$, A. Barreras ${ }^{2}$, L. Corona ${ }^{3}$, F. N. Owens ${ }^{4}$ and A. Plascencia ${ }^{2}$ \\ ${ }^{1}$ Department of Animal Science, University of California, Davis, CA, USA \\ ${ }^{2}$ Instituto de Investigaciones en Ciencias Veterinarias, Universidad Autónoma de Baja California, Mexicali, Baja California, \\ Mexico \\ ${ }^{3}$ Facultad de Medicina Veterinaria y Zootecnia, Universidad Nacional Autónoma de México, Ciudad Universitaria, Mexico \\ ${ }^{4}$ Pioneer Hi-Bred International, Inc., Johnston, IA, USA
}

\section{Abstract}

The primary reason for processing maize is to enhance feeding value. Total tract starch digestion is similar for coarsely processed (dry rolled, cracked) dry maize. Enhancements in starch digestion due to dry rolling maize $v$. feeding maize whole may be greater in lightweight calves than in yearlings, and when $\mathrm{DM}$ intake is restricted $\left(<1.5 \%\right.$ of body weight). The net energy (NE) maintain $\left(\mathrm{NE} \mathrm{m}_{\mathrm{m}}\right)$ and $\mathrm{NE}$ gain $\left(\mathrm{NE}_{\mathrm{g}}\right)$ values for whole maize are 8.83 and $6.02 \mathrm{MJ}(2.11$ and $1.44 \mathrm{Mcal}) / \mathrm{kg}$, respectively. Compared with conventional dry processing (i.e. coarse rolled, cracked), finely processing maize may increase the initial rate of digestion, but does not improve total tract starch digestion. Tempering before rolling (without the addition of steam) may enhance the growth performance response and the NE value of maize. Average total tract starch digestion is similar for high-moisture and steam-flaked maize. However, the proportion of starch digested ruminally is greater (about $8 \%$ ) for high-moisture maize. The growth performance response of feedlot cattle to the feeding of high-moisture maize is highly variable. Although the $\mathrm{NE}_{\mathrm{m}}$ and $\mathrm{NE}_{\mathrm{g}}$ value of whole high-moisture maize was slightly less than that of dry processed maize (averaging 9.04 and $6.44 \mathrm{MJ}(2.16$ and $1.54 \mathrm{Mcal}) / \mathrm{kg}$, respectively), grinding or rolling high-moisture maize before ensiling increased (6\%) its NE value. Substituting steam-flaked maize for dry processed maize increases average daily gain (6.3\%) and decreases DM intake (5\%). The comparative $\mathrm{NE}_{\mathrm{m}}$ and $\mathrm{NE}_{\mathrm{g}}$ values for steam-flaked maize at optimal processing (density $\left.=0.34 \mathrm{~kg} / \mathrm{l}\right)$ are $10 \cdot 04$ and $7 \cdot 07 \mathrm{MJ}(2 \cdot 40$ and $1.69 \mathrm{Mcal}) / \mathrm{kg}$, respectively. These NE values are greater (3\%) than current tabular values (National Research Council, 2000), being more consistent with earlier standards (National Research Council, 1984). When maize is the primary or sole source of starch in the diet, concentration of starch in faeces (faecal starch, \% of DM) of feedlot steers can serve as an indicator of total tract starch digestion, and, hence, the feeding value of maize.

\section{Key words: Maize: Starch digestion: Processing: Feedlot cattle}

\section{Introduction}

'Feeding value' is a complex function of nutrient content, physical and chemical characteristics that affect digestibility, acceptability (palatability) and associative interactions with the digestive process. Consequently, processing methods that might enhance digestion might not be reflected by improved dietary net energy (NE) or growth performance. Thus, processing methods are selected that will most economically enhance digestibility and acceptability without detrimentally affecting ruminal $\mathrm{pH}$ or causing digestive dysfunction. Popular approaches include: (1) particle size reduction that yields dry rolled or dry ground grain with or without the addition of moisture (tempering); (2) ensiling with inherent moisture before the grain has dried in the field to yield high-moisture maize or by adding water to reconstitute maize before ensiling and/or feeding; and (3) steaming flaking. Processing criteria for specific methods vary considerably. These, in combination with differences in feeding management, nutritional balance (nutrient adequacy of dietary formulation) and dietary forage level, make summary comparisons of processing techniques difficult. The objective of the present paper is to provide a practical overview of differences among techniques in terms of digestive function and growth performance of feedlot cattle.

Abbreviations: ADG, average daily gain; DMI, DM intake; FS, faecal starch; H:F, horny:floury; NDF, neutral-detergent fibre; NE, net energy; NE ${ }_{g}$, net energy gain; $\mathrm{NE}_{\mathrm{m}}$, net energy maintain; NRC, National Research Council.

*Corresponding author: Dr Richard Zinn, fax +1 760356 3073, email razinn@ucdavis.edu 


\section{Components of maize grain that limit digestion}

\section{Seed coat}

The seed coat or pericarp of cereal grain serves to protect the seed from moisture, insects and fungal infection that would hamper germination. Although the pericarp comprises only about $4.7 \%$ of the weight of the maize kernel, it contains nearly half of the neutral-detergent fibre (NDF) of the kernel (pericarp averages 10.0\% NDF). For digestion of the starchy endosperm, the seed coat must be cracked to permit moisture, microbes and enzymes to enter. Even after being dry rolled, the pericarp can remain attached to vitreous starch, and thereby might limit access of the endosperm to the processes of fermentation or digestion. Any factor that introduces stress cracks in the pericarp (for example, high-temperature drying of grain, premature harvest) may increase starch exposure and the rate and extent of digestion. Steam flaking and ensiling will reduce the physical association of the pericarp with the endosperm.

The nutrient composition of various fractions of the maize kernel is shown in Fig. $1^{(1)}$. Note that most of the oil and ash is located in the germ whereas the pericarp contains most of the NDF. The surface area of a sphere per unit of volume decreases by half as the diameter doubles. Thus, a larger kernel will have less pericarp as a fraction of total weight; thereby it will have less NDF than a small kernel. This relationship may explain why NE value is greatest for the maize hybrid with the largest mean kernel weight ${ }^{(2)}$. The question is: what determines kernel weight? Grown in the same field in 2002, ten commercial Pioneer maize hybrids had mean kernel weights that ranged from 320 to $401 \mathrm{mg}$; maximum kernel size is characteristic of a hybrid but size can be reduced by water stress or other environmental stresses. Kernel weight also increases with maturity; for certain hybrids,

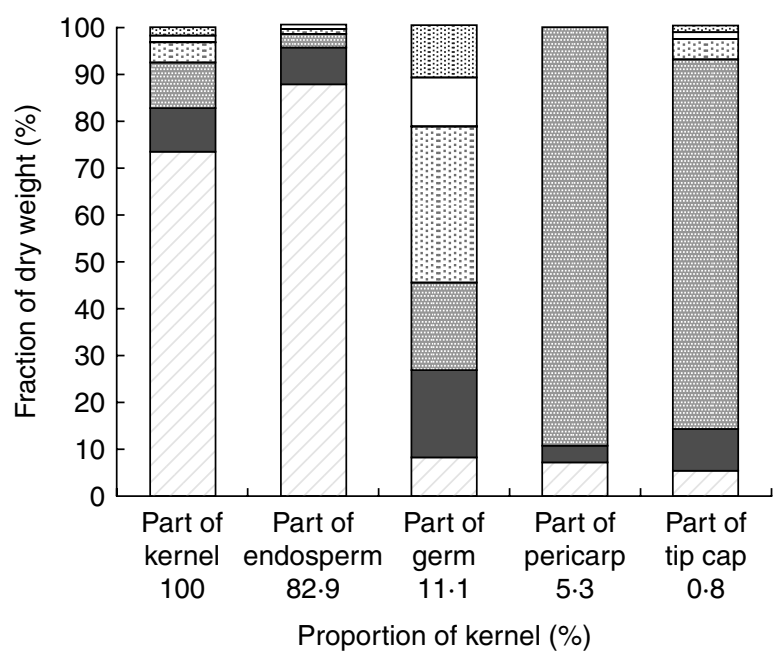

Fig. 1. Nutrient content of various parts of the maize kernel (from Watson ${ }^{(1)}$ ): starch ( $\square$ ); protein ( $\square$ ); neutral-detergent fibre (回); fat (国); ash ( $\square$ ); sugar (国). kernel weight may increase even after kernel moisture falls below 30\% moisture, a point often used to initiate high-moisture maize harvest. Selection of maize with low NDF content or large kernel size should increase the NE value of the grain.

\section{Germ size}

Although a decrease in the relative size of the germ will decrease the ash and NDF content of grain, the germ carries most of the oil and a large proportion of the essential amino acids in maize grain. Consequently, reducing the size of the germ may not enhance the NE value of the grain because the oil content is reduced; it also will decrease the concentration of most essential amino acids. The relative size of the germ is greater for hybrids selected for high oil content. Hybrids marketed as being 'nutrient dense' typically contain more oil than other hybrids. Because ruminal microbes do not ferment oil as a source of energy, microbial protein yield is reduced as oil replaces starch in grain. The value of oil in maize grain depends on its cost relative to other sources of supplemental fat and oil.

\section{Vitreous endosperm}

From 25 to $80 \%$ of the starch is present in the horny (hard or vitreous) endosperm where starch granules are densely packed within a ruminally insoluble and very slowly degradable protein matrix. Yellow maize typically contains approximately $50 \%$ vitreous endosperm. However, white maize may contain $80 \%$ vitreous endosperm. The remaining starch is deposited in the soft or floury endosperm as loosely packed granules resembling basketballs held in a large mesh bag by endosperm cell walls. Vitreousness can be estimated through physical dissection of kernels, by measuring absolute density (not test weight) of the grain, or by grinding with a Stenvert mill. The horny:floury (H:F) ratio varies genetically, being greater for maize grain classified as flint ( $v$. dent). The H:F ratio often increases with grain maturation and $\mathrm{N}$ fertility (that also will increase the crude protein content of maize grain). The rate and extent of digestion of isolated starch granules from the floury endosperm of maize grain are rapid and complete. Thus, primary limitations to the rate and extent of digestion of maize hybrids (in situ) are associated with the $\mathrm{H}$ :F ratio, or degree of vitreousness ${ }^{(3-6)}$.

Floury hybrids generate more fines during grinding. The advantage of having more particles that are very fine is debatable. Increased digestibility should be beneficial, and fine particles may be flushed rapidly through the rumen with fluids, increasing postruminal starch supply. However, fine particles of the floury endosperm are very rapidly fermented, increasing the risk of acidosis. Greater in situ disappearance of floury hybrids has led to the suggestion that the extent of digestion will be greater for hybrids containing more floury and less vitreous 
Table 1. Impact of various processing techniques on maize and its digestion

\begin{tabular}{|c|c|c|c|c|c|c|}
\hline Process & $\begin{array}{l}\text { Expose } \\
\text { endosperm }\end{array}$ & $\begin{array}{l}\text { Reduce } \\
\text { particle } \\
\text { size }\end{array}$ & $\begin{array}{l}\text { Disrupt } \\
\text { endosperm } \\
\text { matrix }\end{array}$ & $\begin{array}{l}\text { Disrupt } \\
\text { starch } \\
\text { granules }\end{array}$ & $\begin{array}{l}\text { Enhance } \\
\text { rate of } \\
\text { fermentation }\end{array}$ & $\begin{array}{l}\text { Enhance } \\
\text { intestinal } \\
\text { digestion }\end{array}$ \\
\hline Dry rolling & +++ & + & - & - & ++ & + \\
\hline Grinding & +++ & +++ & - & - & ++ & + \\
\hline Steam flaking & +++ & ++ & + & + & +++ & ++ \\
\hline Ensiling & + & - & ++ & - & ++ & + \\
\hline
\end{tabular}

+++ , Major impact; ++ , medium impact; + , minor impact; - , no impact.

endosperm when the grain is rolled (not extensively processed). This concept was verified by Jaeger et al. ${ }^{(2)}$ who observed that maize hybrids with greater proportions of floury starch produced the best gain efficiency $(r 0.83)$ when dry rolled.

The optimum H:F ratio may differ with the grain-processing technique employed. Differences in starch digestion among maize hybrids due to vitreousness is apparent with dry rolling, but not with steam flaking ${ }^{(3)}$. Indeed, floury hybrids may complicate the steam-flaking process, yielding more fragile flakes, producing greater fines.

Ensiling influences vitreousness. When subjected to fermentation with maize silage, the vitreousness of starch in maize kernels is reduced ${ }^{(7)}$. When high-moisture maize is prepared from a vitreous and a floury maize hybrid, ruminal and total tract starch digestibility of starch tends to be superior for the vitreous hybrid, as observed in a site of digestion study with steers ${ }^{(8)}$. Thus, extrapolation of hybrid differences from measurements on dry rolled grain to fermented grain or maize silage may prove erroneous.

\section{Amylose content}

Chemically, starch within the starch granules of maize grain is present either as amylopectin in a multi-branched structure or as amylose that is a linear structure and is less rapidly digested by enzymes. Amylose can comprise from below $2 \%$ (waxy maize) to a high of about $70 \%$ (high amylose) of total starch due to genetic differences in activity of the amylose extending gene and enzyme. Environmental factors such as day length also may be involved, as a circadian rhythm in amylose synthesis activity has been detected in some plants. Typical dent maize hybrids have from 24 to $30 \%$ of starch present as amylose. The amylose:amylopectin ratio increases with maize kernel maturity but can be decreased by high environmental temperatures. Maize grain with high amylose content was found to be poorly digested in the small intestine of dogs even after the grain was extruded ${ }^{(9)}$. The susceptibility of flaked high-amylose maize samples to ruminal digestion also is low. Fermentation of amylose may be restricted to a limited number of bacterial strains ${ }^{(10)}$. Starch granules have been proposed to contain consecutive rings or spheres of amylose and amylopectin, and if amylose degradation is limited, granules may resist digestion. Linkage of reducing ends of starch within the starch granule with lipid or P also may reduce the rate of digestion. Small-intestinal digestion of starch from potatoes by lactating cows was found to be nil; in contrast, the small-intestinal digestion of starch was reported to be 70 and $65 \%$ for starch from wheat and maize in a study by van Vuuren et al. ${ }^{(11)}$. Steam flaking removes the feed efficiency advantage of waxy hybrids (low amylose) over typical hybrids (normal amylose) noted in steer performance trials.

\section{Resistant starch}

With exposure to heat and moisture, starch granules swell and form gels, a process called gelatinisation. Swollen particles become enriched in amylopectin as amylose diffuses out of the swollen granules. Starch granules with high amylose content resist swelling. Upon storage of the gelatinised starch, amylose gels and forms retrograde starch. Ward \& Galyean ${ }^{(12)}$ measured in vitro DM disappearance of flaked maize samples that had been held warm in order to decrease starch availability by onethird, presumably due to starch retrogradation. The rate and extent of in vitro digestion were found to be equal for flaked maize despite a reduction in amyloglucosidase reactive starch (increased starch retrogradation). This observation suggests that ruminal microbes from steers fed flaked grain must have sufficient capacity to ferment retrograde starch or at least solubilise starch that might be resistant to attack by starch-degrading enzymes.

Table 2. Effect of processing method on site of starch digestion from maize grain (derived in part from Owens \& Zinn ${ }^{(14)}$ )

\begin{tabular}{lcccccc}
\hline Item & $\begin{array}{c}\text { Dry } \\
\text { whole }\end{array}$ & $\begin{array}{c}\text { Dry } \\
\text { rolled }\end{array}$ & $\begin{array}{c}\text { Dry finely } \\
\text { processed }\end{array}$ & $\begin{array}{r}\text { Tempered } \\
\text { cold rolled }\end{array}$ & $\begin{array}{c}\text { High } \\
\text { moisture }\end{array}$ & $\begin{array}{r}\text { Steam } \\
\text { flaked }\end{array}$ \\
\hline $\begin{array}{l}\text { Diet observations }(n) \\
\text { Starch digestion (\%) }\end{array}$ & 5 & 26 & 1 & 3 & 7 & 93 \\
$\quad$ Ruminal & & 60.6 & & 47.5 & 91.0 & 84.2 \\
$\quad$ Postruminal & & 68.4 & & 80.6 & 90.4 & 94.1 \\
$\quad$ Total tract & 90 & 89.3 & 92 & 89.8 & 99.2 & 99.1 \\
Fraction disappearing in rumen (\%) & & 68.3 & & 52.9 & 91.8 & 84.9 \\
\hline
\end{tabular}


Table 3. Comparative effects of whole dry maize $v$. conventional dry processing (i.e. coarsely rolled, cracked) on average daily weight gain (ADG), $\mathrm{DM}$ intake (DMI) and net energy (NE) value of maize (estimated using the replacement technique and given that $\mathrm{NE}_{\text {maintain }}\left(\mathrm{NE}_{\mathrm{m}}\right)$ of dry rolled maize $=9 \cdot 12 \mathrm{MJ}(2 \cdot 18 \mathrm{Mcal}) / \mathrm{kg} ;$ National Research Council $\left.{ }^{(19)}\right)^{\star}$

\begin{tabular}{|c|c|c|c|c|c|c|c|c|c|c|}
\hline \multirow{2}{*}{$\begin{array}{l}\text { Whole dry maize } \\
\text { Reference }\end{array}$} & \multirow[b]{2}{*}{$n$} & \multicolumn{4}{|c|}{ Change (\%) } & \multicolumn{2}{|c|}{ Maize $\mathrm{NE}_{\mathrm{m}}$} & \multirow{2}{*}{$\begin{array}{l}\text { Test maize } \\
\text { in diet (\%) }\end{array}$} & \multirow[b]{2}{*}{ Sex } & \multirow[b]{2}{*}{ Process } \\
\hline & & $A D G$ & SE & DMI & EE & $\mathrm{MJ} / \mathrm{kg}$ & Mcal/kg & & & \\
\hline Corona et al. ${ }^{(16)}$ & 5 & -8.8 & 0.05 & 5.1 & 0.24 & 8.83 & $2 \cdot 11$ & $75 \cdot 3$ & Steers & Whole \\
\hline Gorocica-Buenfil \& Loerch ${ }^{(17)}$ & 4 & $2 \cdot 3$ & 0.04 & -1.1 & 0.1 & 9.37 & $2 \cdot 24$ & $79 \cdot 8$ & Steers & Whole shelled \\
\hline Scott et al. ${ }^{(20)}$ & 4 & -1.0 & 0.02 & $5 \cdot 7$ & 0.10 & 8.33 & 1.99 & $62 \cdot 5$ & Steers & Whole \\
\hline Average & & -2.5 & & 3.23 & & 8.83 & $2 \cdot 11$ & & & Whole \\
\hline
\end{tabular}

* In this Table, and Tables 4 to 6 , the comparative effects of different maize processing $v$. conventional dry processing (i.e. coarsely rolled, cracked) on ADG and DMI were evaluated using a meta-analysis approach that combines means from individual studies, while taking into account differences in sample sizes. The mean difference or 'effect size' method described by Whitehead \& Whitehead ${ }^{(21)}$ was used. The effect size was calculated as the difference between the means of two studies for ADG and DMI variables. The standardized effect size was estimated by dividing this difference by its pooled SD. Reported SE, and the number of animals in the treatment groups, were used to calculate the pooled SD of each mean difference (Searle et al. ${ }^{(22)}$ ). A fixed-effects statistical model was used and this model included the following factors: study, process, and sex groups. Comparisons between studies were done within sex group. General linear model procedures from SAS were used in the analysis.

Rowe et al. ${ }^{(13)}$ summarised specific responses to various grain-processing techniques on seed components that may limit the site and extent of digestion (Table 1). As will become clear further on in the present paper, processing maize to increase endosperm exposure (usually by particle size reduction) will have very little net impact on feeding value. Enhancement of feeding value will be most predictable with maize-processing techniques that disrupt the endosperm matrix.

\section{Effects of processing on site and extent of starch digestion by cattle}

Results from published trials between 1987 and 2007 that tabulated the site and/or extent of starch digestion for feedlot cattle were assembled (Table 2$)^{(14)}$. Data from trials where mixtures of grains or where grains processed by multiple methods were fed simultaneously were excluded from analysis. Site of digestion measurements with 135 different diets were identified; each measurement was the average of several cattle (mean of 4.5 ) fed each diet. To evaluate the site and extent of starch digestion, factors of primary concern were: (1) percentage of dietary starch apparently digested in the rumen; (2) percentage of starch flowing out of the rumen digested in the intestines; (3) total tract starch digestion; and (4) site of starch digestion (fraction of total tract starch digested that disappeared in the rumen).

Total tract starch digestion was similar for dry processed maize. However, in studies directly comparing dry rolled $v$. whole shelled maize ${ }^{(15-17)}$, dry rolling increased (2 to
$12 \%)$ total tract starch digestion. The postruminal digestion of intact maize kernels is nil. Therefore, intact kernels that escape the rumen are passed as such in the faeces ${ }^{(16)}$. Expected enhancements in starch digestion due to dry rolling maize may be greater in light-weight calves than in yearlings $^{(17)}$, and when comparisons are made at lower levels of intake $\left(<1.5 \%\right.$ of body weight; Murphy et al. $\left.{ }^{(15)}\right)$.

In our experience there continues to be considerable controversy regarding the benefit of finely grinding $v$. dry rolling maize. This concept, although appealing, is not supported by digestion trials, due perhaps, to extensive particle size reduction during the normal course of feeding. Taking into consideration that cattle spend approximately $2 \mathrm{~h} / \mathrm{d}$ eating, with seventy-four jaw movements per min during eating bouts (including the 10-15s laps of no jaw movement between boluses; Kononoff et al. ${ }^{(18)}$ ), a steer consuming $10 \mathrm{~kg}$ of DM will masticate the feed at a rate of 5328 chews $/ \mathrm{kg}$. This of course does not include any additional chewing that might occur during rumination.

Average total tract starch digestion was found to be similar for high-moisture and steam-flaked maize. However, the proportion of starch digested ruminally was greater (8\%) for high-moisture maize (Table 2).

\section{Effects of processing on growth performance and net energy value of maize}

Results from published trials between 1987 and 2007 that directly compared the various processing methods with

Table 4. Comparative effects of finely rolling or grinding dry maize $v$. conventional dry processing (i.e. coarsely rolled, cracked) on average daily weight gain (ADG), DM intake (DMI) and net energy (NE) value of maize (estimated using the replacement technique and given that $\mathrm{NE}$ maintain (NE $\mathrm{m}_{\mathrm{m}}$ ) of dry rolled maize $=9 \cdot 12 \mathrm{MJ}(2 \cdot 18 \mathrm{Mcal}) / \mathrm{kg}$; National Research Council $\left.{ }^{(19)}\right)$

\begin{tabular}{|c|c|c|c|c|c|c|c|c|c|c|}
\hline \multirow{2}{*}{$\begin{array}{l}\text { Finely processed } \\
\text { Reference }\end{array}$} & \multirow[b]{2}{*}{$n$} & \multicolumn{4}{|c|}{ Change (\%) } & \multicolumn{2}{|c|}{ Maize $\mathrm{NE}_{\mathrm{m}}$} & \multirow{2}{*}{$\begin{array}{l}\text { Test maize } \\
\text { in diet }(\%)\end{array}$} & \multirow[b]{2}{*}{ Sex } & \multirow[b]{2}{*}{ Process } \\
\hline & & ADG & $\mathrm{SE}$ & DMI & SE & $\mathrm{MJ} / \mathrm{kg}$ & Mcal/kg & & & \\
\hline Corona et al..$^{(16)}$ & 5 & -3.7 & 0.05 & $-2 \cdot 0$ & 0.24 & 8.95 & $2 \cdot 14$ & $75 \cdot 3$ & Steers & Finely ground \\
\hline Scott et al. ${ }^{(20)}$ & 4 & -1.6 & 0.02 & -4.7 & 0.10 & 9.41 & $2 \cdot 25$ & 62.5 & Steers & Finely ground \\
\hline Scott et al. ${ }^{(20)}$ & 4 & $-1 \cdot 1$ & 0.03 & 0.0 & 0.10 & 9.00 & $2 \cdot 15$ & 62.5 & Steers & Finely ground \\
\hline Loe et al. ${ }^{(23)}$ & 6 & 3.9 & 0.04 & 4.9 & 0.30 & 8.83 & $2 \cdot 11$ & $42 \cdot 0$ & Steers & Finely rolled \\
\hline Average & & -0.6 & & -0.5 & & 9.04 & $2 \cdot 16$ & & & \\
\hline
\end{tabular}


Table 5. Comparative effects of high-moisture $v$. conventional dry processing (i.e. coarsely rolled, cracked) on average daily weight gain (ADG), DMI and net energy (NE) value of maize (estimated using the replacement technique and given that $\mathrm{NE}$ maintain $\left(\mathrm{NE}_{\mathrm{m}}\right)$ of $\mathrm{dry}$ rolled maize $=9 \cdot 12 \mathrm{MJ}$ $(2 \cdot 18 \mathrm{Mcal}) / \mathrm{kg}$; National Research Council $\left.{ }^{(19)}\right)$

\begin{tabular}{|c|c|c|c|c|c|c|c|c|c|c|c|}
\hline \multirow{2}{*}{$\begin{array}{l}\text { High-moisture maize } \\
\text { Reference }\end{array}$} & \multirow[b]{2}{*}{$n$} & \multicolumn{4}{|c|}{ Change (\%) } & \multicolumn{2}{|c|}{ Maize $\mathrm{NE}_{\mathrm{m}}$} & \multirow{2}{*}{$\begin{array}{l}\text { Test maize } \\
\text { in diet (\%) }\end{array}$} & \multirow[b]{2}{*}{ Sex } & \multirow[b]{2}{*}{ Process } & \multirow[b]{2}{*}{ Moisture (\%) } \\
\hline & & $A D G$ & SE & DMI & SE & $\mathrm{MJ} / \mathrm{kg}$ & $\mathrm{Mcal} / \mathrm{kg}$ & & & & \\
\hline Huck et al. ${ }^{(27)}$ & 5 & $-1 \cdot 1$ & 0.05 & -3.8 & 0.14 & 9.50 & $2 \cdot 27$ & 74.5 & Steers & Rolled & 35 \\
\hline Ladely et al. ${ }^{(28)}$ & 4 & $-4 \cdot 0$ & 0.03 & $-15 \cdot 0$ & 0.18 & $10 \cdot 13$ & $2 \cdot 42$ & 83.4 & Heifers & Ground & 28 \\
\hline Ladely et al. ${ }^{(28)}$ & 4 & $5 \cdot 4$ & 0.09 & -4.4 & 0.20 & 9.83 & $2 \cdot 35$ & 83.2 & Steers & Ground & 29 \\
\hline Ladely et al. ${ }^{(28)}$ & 4 & 0.0 & 0.03 & $-15 \cdot 2$ & 0.18 & $10 \cdot 67$ & 2.55 & $83 \cdot 4$ & Heifers & Ground & 28 \\
\hline Ladely et al. ${ }^{(28)}$ & 4 & -3.7 & 0.09 & -7.6 & 0.20 & $9 \cdot 46$ & $2 \cdot 26$ & 83.2 & Steers & Ground & 29 \\
\hline Ladely et al. ${ }^{(28)}$ & 4 & $6 \cdot 1$ & 0.09 & -6.5 & 0.20 & 10.08 & $2 \cdot 41$ & 83.2 & Steers & Ground & 29 \\
\hline Archibeque et al. & 5 & $-5 \cdot 8$ & 0.03 & -3.8 & 0.12 & 9.00 & $2 \cdot 15$ & 78.7 & Steers & Ground & 35 \\
\hline Stock et al. ${ }^{(30)}$ & 5 & 0.7 & 0.04 & $-8 \cdot 7$ & 0.19 & $10 \cdot 00$ & $2 \cdot 39$ & 78.0 & Steers & Ground & 25 \\
\hline Stock et al. ${ }^{(30)}$ & 3 & $-5 \cdot 1$ & 0.05 & -0.30 & 0.24 & 8.74 & 2.09 & $80 \cdot 0$ & Steers & Ground & 27 \\
\hline Scott et al. ${ }^{(20)}$ & 4 & $-2 \cdot 1$ & 0.20 & $-6 \cdot 6$ & 0.10 & 9.87 & $2 \cdot 36$ & 52.5 & Steers & Ground & 29 \\
\hline Scott et al. ${ }^{(20)}$ & 4 & 0.6 & 0.03 & -0.9 & 0.10 & 9.37 & $2 \cdot 24$ & 62.5 & Steers & Ground & 29 \\
\hline Average & & -0.8 & & $-6 \cdot 6$ & & 9.67 & $2 \cdot 31$ & & & & \\
\hline
\end{tabular}

dry processed (coarsely rolled or cracked) maize were evaluated. In all cases, a $\mathrm{NE}$ maintain $\left(\mathrm{NE}_{\mathrm{m}}\right)$ value of $9 \cdot 12 \mathrm{MJ}(2 \cdot 18 \mathrm{Mcal}) / \mathrm{kg}$ was assigned to the control, dry process treatment to which all of the process treatments below were compared using the replacement technique. Likewise, changes in average daily gain (ADG) and DM intake (DMI) are with reference to the control (dry process treatment). The comparative effects of whole dry shelled maize $v$. dry rolled maize are summarised in Table 3 $(16,17,19-22)$. Feeding whole shelled maize tends to decrease ADG by $2.5 \%$ and increase DMI by $3.2 \%$. The $\mathrm{NE}_{\mathrm{m}}$ and NE gain $\left(\mathrm{NE}_{\mathrm{g}}\right)$ values for whole shelled maize are 8.83 and $6.02 \mathrm{MJ}(2 \cdot 11$ and $1.44 \mathrm{Mcal}) / \mathrm{kg}$, respectively. The only slight reduction in NE $(3.2 \%)$ due to not processing maize is consistent with expected values based on starch digestion studies (Table 2). The National Research Council $(\mathrm{NRC})^{(19)}$ does not differentiate the NE value of maize for whole $v$. dry processes. Likewise, the comparative effects of finely rolling or grinding dry maize $v$. coarse processing (Table 4$)^{(16,19,20,23)}$ on growth performance and maize NE are minimal $(<1 \%$ change)
The growth performance response of feedlot cattle to feeding of high-moisture maize is highly variable. Previous studies indicate that high-moisture maize increases diet acceptability over that of dry processed maize, increasing ADG and DMI by $2 \cdot 9$ and $3 \cdot 2 \%$, respectively ${ }^{(24-26)}$. However, the NE value of whole high-moisture maize is similar to or slightly less than that of dry processed maize, averaging 9.04 and $6.44 \mathrm{MJ}(2.16$ and $1.54 \mathrm{Mcal}) /$ $\mathrm{kg}$, respectively ${ }^{(24-26)}$. Grinding or rolling high-moisture maize before ensiling increases its NE value; however, these processes also increased the likelihood for depressed ADG compared with ensiling the maize whole. The comparative effects of processed high-moisture $v$. conventional dry processed maize on the ADG, DMI and NE value of maize are shown in Table $5^{(19,20,27-30)}$. Substituting processed high-moisture maize for dry processed maize does not affect ADG, but reduces $(P<0.05)$ DMI by $6 \cdot 6 \%$. Consequently, the $\mathrm{NE}_{\mathrm{m}}$ and $\mathrm{NE}_{\mathrm{g}}$ values for highmoisture maize are greater than that of dry processed maize, averaging 9.67 and $6.74 \mathrm{MJ}(2.31$ and $1.61 \mathrm{Mcal}) / \mathrm{kg}$, respectively. These values are consistent with those

Table 6. Comparative effects of steam flaking $v$. conventional dry processing (i.e. coarsely rolled, cracked) on average daily weight gain (ADG), DM intake (DMI) and net energy (NE) value of maize (estimated using the replacement technique and given that $\mathrm{NE}$ maintenance $\left(\mathrm{NE}_{\mathrm{m}}\right)$ of dry rolled maize $=9 \cdot 12 \mathrm{MJ}(2 \cdot 18 \mathrm{Mcal}) / \mathrm{kg}$; National Research Council $\left.{ }^{(19)}\right)$

\begin{tabular}{|c|c|c|c|c|c|c|c|c|c|c|}
\hline \multirow{2}{*}{$\begin{array}{l}\text { Steam-flaked maize } \\
\text { Reference }\end{array}$} & \multicolumn{5}{|c|}{ Change (\%) } & \multicolumn{2}{|c|}{ Maize $\mathrm{NE}_{\mathrm{m}}$} & \multirow{2}{*}{$\begin{array}{l}\text { Test maize } \\
\text { in diet (\%) }\end{array}$} & \multirow[b]{2}{*}{ Sex } & \multirow{2}{*}{$\begin{array}{l}\text { Flake density } \\
\qquad(\mathrm{kg} / \mathrm{l})\end{array}$} \\
\hline & $n$ & ADG & SE & DMI & SE & $\mathrm{MJ} / \mathrm{kg}$ & Mcal/kg & & & \\
\hline $\operatorname{Zinn}^{(31)}$ & 18 & 1.7 & 0.02 & $-6 \cdot 8$ & 0.08 & $10 \cdot 38$ & $2 \cdot 48$ & $50 \cdot 6$ & Steers & 0.31 \\
\hline Huck et al. (27) & 5 & $7 \cdot 7$ & 0.05 & -0.9 & 0.14 & $10 \cdot 00$ & 2.39 & 74.5 & Steers & 0.36 \\
\hline Zinn et al. ${ }^{(32)}$ & 5 & $4 \cdot 1$ & 0.11 & -6.9 & 0.36 & $10 \cdot 42$ & 2.49 & $65 \cdot 0$ & Steers & 0.31 \\
\hline Barajas \& Zinn ${ }^{(33)}$ & 4 & $8 \cdot 2$ & 0.06 & $-10 \cdot 1$ & 0.28 & $10 \cdot 71$ & 2.56 & $74 \cdot 1$ & Heifers & 0.31 \\
\hline Barajas \& Zinn ${ }^{(33)}$ & 4 & 6.9 & 0.06 & -6.6 & 0.28 & $10 \cdot 33$ & 2.47 & $64 \cdot 1$ & Heifers & 0.31 \\
\hline Scott et al. & 4 & $6 \cdot 1$ & 0.10 & $-3 \cdot 6$ & 0.03 & $10 \cdot 21$ & 2.44 & 62.5 & Steers & 0.37 \\
\hline Scott et al. ${ }^{(20)}$ & 4 & 0.5 & 0.10 & $-5 \cdot 7$ & 0.02 & $10 \cdot 17$ & 2.43 & 52.5 & Steers & 0.37 \\
\hline Scott et al. ${ }^{(20)}$ & 4 & $10 \cdot 2$ & 0.03 & $1 \cdot 0$ & 0.01 & $9 \cdot 87$ & $2 \cdot 36$ & 82.5 & Steers & 0.37 \\
\hline Scott et al. ${ }^{(20)}$ & 4 & 3.4 & 0.02 & $-1 \cdot 1$ & 0.10 & $9 \cdot 54$ & $2 \cdot 28$ & 81.55 & Steers & 0.37 \\
\hline Corona et al. ${ }^{(16)}$ & 5 & 4.4 & 0.05 & $-8 \cdot 1$ & 0.24 & $10 \cdot 38$ & 2.48 & $75 \cdot 3$ & Steers & 0.31 \\
\hline Brown et al. ${ }^{(34)}$ & 6 & $4 \cdot 3$ & 0.22 & -9.7 & 0.06 & $10 \cdot 71$ & 2.56 & 76.55 & Steers & 0.20 \\
\hline Brown et al. ${ }^{(34)}$ & 6 & $17 \cdot 7$ & 0.22 & $-1 \cdot 2$ & 0.06 & 10.96 & 2.62 & 76.55 & Steers & 0.28 \\
\hline Average & & $6 \cdot 26$ & & -4.97 & & $10 \cdot 29$ & 2.46 & & & \\
\hline
\end{tabular}


Fig. 2. Relationship between faecal starch (FS) percentage and total tract starch digestion (starch digestion (\%) $=99.9$ (SE 0.0540$)-0.413$ (SE 0.0306 ) $\mathrm{FS}-0.0131$ (SE 0.00192$) \mathrm{FS}^{2} ; R^{2} 0.96$ ) (from Zinn et al. ${ }^{(36)}$ ).

suggested for high-density high-moisture maize $(25.4 \mathrm{~kg}$ $(56 \mathrm{lb}) /$ bushel) by the $\mathrm{NRC}^{(19)}$. The improvements in $\mathrm{NE}$ value of ensiled high-moisture maize are also consistent with the expected enhancement in starch digestion (Table 1).

Consistent with previous reviews, substituting steamflaked maize for dry processed maize increases $(P<0.05)$ ADG (6.3\%) and decreases DMI (5\%). The comparative $\mathrm{NE}_{\mathrm{m}}$ and $\mathrm{NE}_{\mathrm{g}}$ values for steam-flaked maize are 10.29 and $7.32 \mathrm{MJ}(2.46$ and $1.75 \mathrm{Mcal}) / \mathrm{kg}$, respectively (Table 6) $(16,19,20,27,31-34)$. The NE values are greater $(5 \cdot 5 \%)$ than current tabular values ${ }^{(19)}$, being more consistent with earlier standards ${ }^{(35)}$.

\section{Optimising processing conditions}

Due to maize's high starch content, assessment of changes in starch enzymic reactivity, and/or digestibility have been used to optimise processing techniques. However, when grain is the primary or sole source of starch in the diet, concentration of starch in the faeces (faecal starch (FS), \% of DM) of feedlot steers can serve as an indicator of total tract starch digestion, and, hence, the feeding value of maize. Zinn et al. ${ }^{(36)}$, using a regression analysis, evaluated data from thirty-two metabolism trials involving 637 individual starch digestibility measurements. Percentage FS explained $96 \%$ of the variation in total tract starch digestion $\quad\left(\right.$ TSD $\quad(\%)=99 \cdot 9-0.413 \quad$ FS $-0.0131 \quad \mathrm{FS}^{2}$

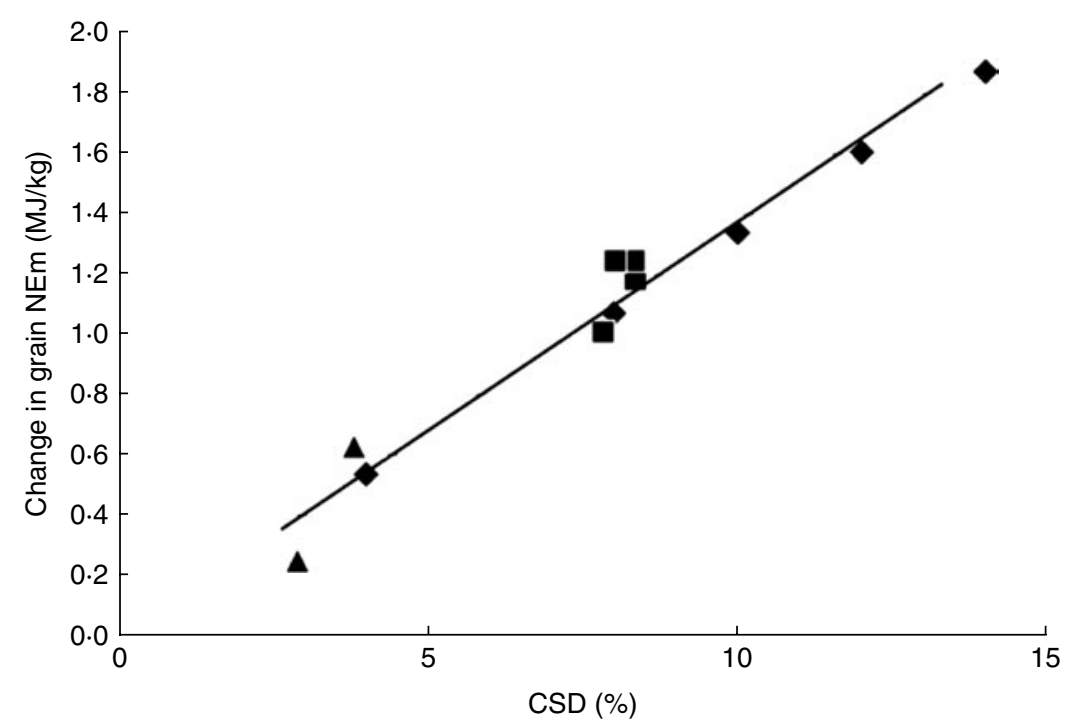

Fig. 3. Relationship between change in total tract starch digestion (CSD, \%) and change in grain (maize $(\bullet)$, wheat $(\mathbf{\Lambda})$, sorghum $(\boldsymbol{\square}))$ net energy maintain $\left(\mathrm{NE}_{\mathrm{m}}\right)$ : change in grain $\mathrm{NE}_{\mathrm{m}}(\mathrm{MJ} / \mathrm{kg})=0.1372 \mathrm{CSD}(\%)$ (change in grain $\left.\mathrm{NE}_{\mathrm{m}}(\mathrm{Mcal} / \mathrm{kg})=0.0328 \mathrm{CSD}(\%)\right)\left(r^{2} 0.97\right.$; standard error of the estimate $\left(\mathrm{S}_{\mathrm{y} . \mathrm{x}}\right)=0.022$; $P<0.001$ ) (from Zinn et al. ${ }^{(37)}$ ). 
(Zinn et al. ${ }^{(36)}$; Fig. 2). Zinn et al. ${ }^{(37)}$ observed that starch digestion was closely associated $\left(r^{2}\right.$ 0.88) with the $\mathrm{NE}$ value of maize (Fig. 3): maize $\mathrm{NE}_{\mathrm{m}}(\mathrm{MJ} / \mathrm{kg})=$ $-3.14+0.134$ TSD (maize $\mathrm{NE}_{\mathrm{m}}(\mathrm{Mcal})=-0.75+0.032$ TSD). Thus, where maize is the principle source of dietary starch: maize $\mathrm{NE}_{\mathrm{m}}(\mathrm{MJ} / \mathrm{kg})=10 \cdot 21-0.0552 \mathrm{FS}-0.00175$ $\mathrm{FS}^{2}$ and $\mathrm{NE}_{\mathrm{g}}(\mathrm{MJ} / \mathrm{kg})=3.67 \quad \mathrm{NE}_{\mathrm{m}}-1.72$ (maize $\mathrm{NE}_{\mathrm{m}}$ $\left.(\mathrm{Mcal})=2.44-0.0132 \quad \mathrm{FS}-0.000418 \mathrm{FS}^{2}\right)$, and $\mathrm{NE}_{\mathrm{g}}$ $\left.(\mathrm{Mcal})=0.877 \mathrm{NE}_{\mathrm{m}}-0.41\right)$. This relationship also applies to sorghum and wheat.

\section{Example of assessment of maize processing method}

For practical assessments of the adequacy of maize processing under feedlot conditions, consider the following example:

The problem. A feedlot is steam flaking maize but is not certain what flake density (as measured directly beneath the rolls) is optimal under their production system.

The evaluation. Set the ram pressure to produce flaked maize at a density of $0.36 \mathrm{~kg} / 1(12.7 \mathrm{~kg}(28 \mathrm{lbs}) / \mathrm{bushel})$. After feeding the flaked maize for $5 \mathrm{~d}$, collect twelve faecal grab samples (about $100 \mathrm{~g} /$ sample) from three pens (four samples/pen) receiving the finishing diet. Faecal samples may be collected in the early daylight hours when cattle are just getting up. Dry the faecal material as soon as possible following collection, and determine percentage FS in the dried sample.

The result. FS analysis for the composite sample averaged $4.5 \%$. Thus, starch digestion $=97.8 \%$ and maize $\mathrm{NE}_{\mathrm{m}}=9.92 \mathrm{MJ}(2.37 \mathrm{Mcal})$.

The solution. Increase ram pressure to produce a flake density of $0.34 \mathrm{~kg} / 1$, feed maize for $5 \mathrm{~d}$ and repeat FS evaluation. A practical target for FS might be $<3.0 \%$. This will result in an expected $\mathrm{NE}_{\mathrm{m}}$ value for flaked maize of $10 \cdot 04 \mathrm{MJ}(2 \cdot 40 \mathrm{Mcal}) / \mathrm{kg}$.

\section{Conclusions}

The NE values of whole and dry rolled maize are consistent with current standards $\left(\mathrm{NRC}^{(19)}\right)$. The NE value of whole high-moisture maize is only slightly $(2 \cdot 3 \%)$ greater than that of dry processed maize, and 5.5\% less than that suggested by the $\mathrm{NRC}^{(19)}$. Softening the kernel before rolling by tempering or steaming enhances the growth performance response and the $\mathrm{NE}$ value of maize as a result of increased total tract starch digestion. The feeding value of maize may be affected by the intensity of processing only in steam-flaked processing. The comparative $\mathrm{NE}_{\mathrm{m}}$ and $\mathrm{NE}_{\mathrm{g}}$ values for steam-flaked maize at optimal processing (density $=0.34 \mathrm{~kg} / \mathrm{l}$ ) are 10.04 and $7.07 \mathrm{MJ}$ ( 2.40 and $1.69 \mathrm{Mcal}) / \mathrm{kg}$, respectively. These $\mathrm{NE}$ values are greater (3\%) than current tabular values ${ }^{(19)}$, being more consistent with earlier standards ${ }^{(35)}$. When maize is the primary or sole source of starch in the diet, the concentration of starch in faeces (FS, \% of DM) of feedlot steers can serve as an indicator of total tract starch digestion, and, hence, the feeding value of maize.

\section{Acknowledgements}

The present review received no specific grant from any funding agency in the public, commercial or not-forprofit sectors.

The authors contribution to the manuscript were as follows: R. Z. and F. O., design and draft of the work; A. B. statistical analysis; L. C., literature review and A. P., statistical analysis and style revision.

There are no conflicts of interest in the subject of the present review.

\section{References}

1. Watson SA (1987) Description, development, structure and composition of the corn kernel. In Corn: Chemistry and Technology, 2nd ed., pp. 53-82 [SA Watson and PA Ramstad, editors]. St Paul, MN: American Association of Cereal Chemists.

2. Jaeger SL, Luebbe MK, Macken CN, et al. (2006) The influence of corn hybrid traits on digestibility and efficiency of gain in feedlot cattle. J Anim Sci 84, 1790-1800.

3. Corona L, Owens FN \& Zinn RA (2006) Impact of corn vitreousness and processing on site and extent of digestion by feedlot cattle. J Anim Sci 84, 3020-3031.

4. Philippeau C, Le Deschault de Monredon F \& MichaletDoreau B (1999) Relationship between ruminal starch degradation and the physical characteristics of corn grain. J Anim Sci 77, 238-243.

5. Philippeau C, Martin C \& Michalet-Doreau B (1999) Influence of grain source on ruminal characteristics and rate, site, and extent of digestion in beef steers. J Anim Sci 77, $1587-1596$.

6. Shaver RD \& Majee D (2002) Relationship between corn vitreousness and starch digestion. In Cornell Nutrition Conference 2002 Proceedings, pp. 153-158.

7. Johnson LM, Harrison JH, Davidson D, et al. (2002) Corn silage management I: effects of hybrid, maturity, and mechanical processing on chemical and physical characteristics. J Dairy Sci $\mathbf{8 5}, 833-853$

8. Szasz JI, Hunt CW, Szasz PA, et al. (2007) Influence of endosperm vitreousness and kernel moisture at harvest on site and extent of digestion of high-moisture corn by feedlot steers. J Anim Sci 85, 2214-2221.

9. Gajda M, Flickinger EA, Grieshop CM, et al. (2005) Corn hybrid affects in vitro and in vivo measures of nutrient digestibility in dogs. J Anim Sci 83, 160-171.

10. Wang X, Conway PL, Brown IL, et al. (1999) In vitro utilization of amylopectin and high-amylose maize (amylomaize) starch granules by human colonic bacteria. Appl Environ Microbiol 65, 4848-4854.

11. van Vuuren AM, Hindle VA \& Cone JW (2004) Effect of starch source on supply of glycogenic nutrients in dairy cows. J Dairy Sci 87, Suppl. 1, 463.

12. Ward CF \& Galyean ML (1999) The relationship between retrograde starch as measured by starch availability estimates and in vitro dry matter disappearance of steam-flaked corn. Burnett Center Internet Progress Report No. 2. http://www. depts.ttu.edu/afs/burnett_center/progress_reports/bc2.pdf (accessed August 2011). 
13. Rowe JB, Choct M \& Pethick DW (1999) Processing cereal grains for animal feeding. Aust J Agric Res 50, 721-736.

14. Owens FN \& Zinn RA (2005) Corn grain for cattle: influence of processing on site and extent of digestion. In Proceedings of the 20th Southwest Nutrition Conference, pp. $86-112$

15. Murphy TA, Fluharty FL \& Loerch SC (1994) The influence of intake level and corn processing on digestibility and ruminal metabolism in steers fed all-concentrate diets. J Anim Sci $\mathbf{7 2}$, 1608-1615.

16. Corona L, Rodriguez S, Ware RA, et al. (2005) Comparative effect of whole, ground, dry-rolled and steam-flaked corn on digestion and growth performance in feedlot cattle. Prof Anim Sci 21, 200-206.

17. Gorocica-Buenfil MA \& Loerch SC (2005) Effect of cattle age, forage level, and corn processing on diet digestibility and feedlot performance. J Anim Sci 83, 705-714.

18. Kononoff PJ, Heinrichs AJ \& Lehman HA (2002) Technical note: a comparison of method used to measure eating and ruminating activity in confined dairy cattle. J Dairy Sci $\mathbf{8 5}$, 1801-1803.

19. National Research Council (2000) Nutrient Requirement of Beef Cattle, 7th revised ed.. Washington, DC: National Academy Press.

20. Scott TL, Milton CT, Erickson GE, et al. (2003) Corn processing method in finishing diets containing wet corn gluten feed. J Anim Sci 81, 3182-3190.

21. Whitehead A \& Whitehead J (1991) A general parametric approach to the meta-analysis of randomized clinical trials. Stat Med 10, 1665-1677.

22. Searle SR, Casella G \& McCulloch CE (1992) Variance Components. Wiley Series in Probability and Mathematical Statistics. New York, NY: John Wiley and Sons.

23. Loe ER, Bauer ML \& Lardy GP (2006) Grain source and processing in diets containing varying concentrations of wet corn gluten feed for finishing cattle. J Anim Sci $\mathbf{8 4}$, 986-996.

24. Mader TL, Dahlquist JM, Britton RA, et al. (1991) Type and mixtures of high-moisture corn in beef cattle finishing diets. J Anim Sci 69, 3480-3486.

25. Stock RA, Brink DR, Brandt RT, et al. (1987) Feeding combinations of high moisture corn and dry corn to finishing cattle. J Anim Sci 65, 282-289.
26. Utley PR \& McCormick WC (1975) Dry or high-moisture corn for finishing steers in drylot or on oat pasture. J Anim Sci $\mathbf{4 1}$, 495-499.

27. Huck GL, Kreikemeier KK, Kul GL, et al. (1998) Effects of feeding combinations of steam-flaked grain sorghum and steam-flaked, high-moisture, or dry-rolled corn on growth performance and carcass characteristics in feedlot cattle. J Anim Sci 76, 2984-2990.

28. Ladely SR, Stock RA, Goedeken FK, et al. (1995) Effect of corn hybrid and grain processing method on rate of starch disappearance and performance of finishing cattle. J Anim Sci 73, 360-364.

29. Archibeque SL, Miller DN, Freely HC, et al. (2006) Feeding high-moisture corn instead of dry-rolled corn reduces odorous compound production in manure of finishing beef cattle without decreasing performance. J Anim Sci 84, 1767-1777.

30. Stock RA, Sindt MH, Cleale RM IV, et al. (1991) Highmoisture corn utilization in finishing cattle. J Anim Sci 69 , 1645-1656.

31. Zinn RA (1987) Influence of lasalocid and monensin plus tylosin on comparative feeding value of steam-flaked versus dryrolled corn in diets for feedlot cattle. J Anim Sci 65, 256-266.

32. Zinn RA, Alvarez EG, Montano MF, et al. (1998) Influence of tempering on the feeding value of rolled corn in finishing diets for feedlot cattle. J Anim Sci 76, 2239-2246.

33. Barajas R \& Zinn RA (1998) The feeding value of dry-rolled and steam-flaked corn in finishing diets for feedlot cattle: influence of protein supplementation. J Anim Sci 76, $1744-1752$.

34. Brown MS, Krehbiel CR, Duff GC, et al. (2000) Effect of degree of corn processing on urinary nitrogen composition, serum metabolite and insulin profiles, and performance by finishing steers. J Anim Sci 78, 2464-2474.

35. National Research Council (1984) Nutrient Requirement of Beef Cattle, 6th revised ed. Washington, DC: National Academy Press.

36. Zinn RA, Barreras A, Corona L, et al. (2007) Starch digestion by feedlot cattle: predictions from analysis of feed and fecal starch and nitrogen. J Anim Sci 85, 1727-1730.

37. Zinn RA, Owens FN \& Ware RA (2002) Flaking corn: processing mechanics, quality standards, and impacts on energy availability and performance of feedlot cattle. J Anim Sci 80, 1145-1156 